\title{
Nonword Repetition of Typically Developing Children
}

\author{
Mina Hwang \\ Department of Special Education, Dankook University, Yongin, Korea
}

\author{
Correspondence: Mina Hwang, PhD, CCC-SLP \\ Department of Special Education, Dankook \\ University, 152 Jukjeon-ro, Suji-gu, Yongin 16890, \\ Korea \\ Tel: +82-31-8005-3816 \\ Fax: +82-31-8021-7228 \\ E-mail: hwangm@dankook.ac.kr
}

Received: July 3, 2015

Revised: August 27, 2015

Accepted: August 31, 2015

The present research was conducted by the research fund of Dankook University in 2014 .
Objectives: The purpose of the present study was to investigate the effects of nonword length and phonological complexity on the performances of nonword repetition in Korean-speaking children. Methods: Typically developing Korean-speaking children of age 5 to $9(\mathrm{~N}=152)$ participated in this study. They were asked to repeat 32 nonwords of different lengths (2 to 5 syllables) and of two levels of phonological complexity. Two scoring methods were applied: total number of correctly repeated nonwords and percentage of correctly repeated syllables. Results: A three-way ANOVA of age $\times$ nonword length $\times$ phonological complexity revealed statistically significant main effects of age, nonword length, and phonological complexity and a significant interaction between nonword length and age. In other words, the older children repeated nonwords more accurately than the younger children, and the children experienced more difficulty in correctly repeating the longer or phonologically complex nonwords relative to the shorter or phonologically simple nonwords. The effect of nonword length on children's repetition performances decreased with age. Conclusion: The results indicated that Korean-speaking children of age 5 to 9 repeat nonwords more accurately as they grow up. The effects of nonword length and phonological complexity on nonword repetition were consistent with the results of previous studies (e.g., Gallon, Harris, \& Van der Lely, 2007; Munson, Kurtz, \& Windsor, 2005). How the differences in the features of nonwords, test procedures, and scoring systems may affect children's performances on nonword repetition tests was discussed.

Keywords: Nonword repetition test, Nonword length, Phonological complexity of nonwords
비단어 따라말하기는 모국어 음소들의 연쇄로 구성되었지만, 해 당 언어의 단어가 아닌 비단어를 듣고 따라말하는 검사이다. 표면 적으로는 단순한 검사이지만, 비단어 따라말하기를 정확하게 수행 하기 위해서는 적절한 지각, 언어처리, 기억 및 말산출 능력이 필요 하다. 비단어를 듣는 순간 음향신호를 지각하고, 그 음향신호를 음 운적으로 표상하여 기억해야 하며, 기억한 음운표상을 발음하기 위하여 조음 움직임을 계획하고, 말산출을 위한 근육운동을 실행 하여야 한다. 아동이 자라면서 비단어 따라말하기 수행을 위해 필 요한 이러한 구성 요소들의 처리 능력들이 발달하고, 따라서 아동 기의 비단어 따라말하기 수행은 연령이 증가하면서 향상된다(Archibald \& Joanisse, 2009; Chiat \& Roy, 2007; Gathercole \& Baddeley, 1989; Roy \& Chiat, 2004). 결국, 아동들이 비단어를 따라말 할 때 보이는 수행의 개인차는 아동의 청각정보 재인 및 처리 능력,
말소리 특질에 대한 변별 정확도, 음운 표상의 견고성 혹은 체계화 정도, 비단어의 음운정보를 기억 저장하는 능력, 말소리 산출을 위 한 운동 프로그래밍 능력 및 조음의 발달 정도 등에 영향을 받는 데, 연구자들은 특히 비단어 따라말하기 수행이 아동의 음운작업 기억 능력을 반영한다는 데에 관심을 가져왔다(Gathercole \& Baddeley, 1989; Gathercole, Willis, Baddeley, \& Emslie, 1994). 비단어 따라말하기 검사로 측정된 음운작업기억 능력은 아동의 어휘 습 득과 밀접하게 관련된다는 연구 결과들이 보고되었고(Gathercole \& Baddeley, 1989; Gathercole, Willis, Emslie, \& Baddeley, 1992), 단순언어장애 아동들의 비단어 따라말하기 수행이 일반아동들에 비하여 유의미하게 저조하다는 연구 결과들에 근거하여, 많은 연 구자들은 단순언어장애 아동의 언어습득과 처리 어려움이 이들의 음운작업기억 능력의 결함과 직접적으로 관련된다고 주장하였다 
(Archibald \& Gathercole, 2006; Bishop, North, \& Donlan, 1996; Conti-Ramsden, 2003; Conti-Ramsden, Botting, \& Faragher, 2001; Conti-Ramsden \& Hesketh, 2003; Dollaghan \& Campbell, 1998; Gathercole \& Baddeley, 1990; Montgomery, 1995).

단순언어장애 아동들의 비단어 따라말하기 수행 결함은 주로 영어권 연구들에서 보고되었으나, 스페인어, 스웨덴어, 프랑스어, 네덜란드어, 이탈리아어 등 다양한 언어권의 연구들에서도 단순언 어장애 아동들의 비단어 따라말하기 수행 결함이 관찰되었다(Bortolini et al., 2006; Girbau \& Schwartz, 2007; Rispens \& Parigger, 2010; Sahlen, Reuterskiold-Wagner, Nettelbladt, \& Radeborg, 1999; Thordardottir et al., 2011). 이와 같이 단순언어장애 아동들이 일관 되게 비단어 따라말하기 검사에서 저조한 수행을 보이는 연구결과 들이 보고됨에 따라 단순언어장애 아동들을 일반아동으로부터 선 별하는 도구로써 비단어 따라말하기 검사의 유용성이 부각되었다. 그런데, 비단어 따라말하기가 단순언어장애 아동들을 얼마나 민 감하고 정확하게 선별하는지는 연구들마다 상이하게 나타났다. 비 단어 따라말하기 검사 점수를 통해 단순언어장애 아동들을 일반 아동들로부터 거의 정확하게 가려낼 수 있다고 보고한 연구도 있지 만(Dollaghan \& Campbell, 1998), 비단어 따라말하기 검사 단독으 로는 단순언어장애 아동을 선별하기에 충분하지 못하므로 문장 따라말하기와 같은 다른 측정치와 함께 사용하는 것을 권장하는 연구자들도(Archibald \& Joanisse, 2009; Conti-Ramsden, et al., 2001)있었다. 흥미롭게도, 광둥어를 사용하는 단순언어장애아동 들의 경우, 비단어 따라말하기 수행이 생활연령이 같은 또래아동 들에 비해서도 낮지 않았다(Stokes, Wong, Fletcher, \& Leonard, 2006). 이는 영어를 비롯한 다른 언어권 연구들에서 단순언어장애 아동들의 비단어 따라말하기 수행이 최소한 또래 아동들에 비해 서는 유의미하게 저조했던 선행 연구들과는 대조되는 결과이다. Stokes 등(2006)은 이러한 결과가 영어와 구별되는 광둥어 비단어 들의 음운특성에 기인하는 것으로 추정하였다.

아동의 비단어 따라말하기 수행에서의 차이가 언어간 차이에만 기인하는 것은 아니다. 같은 언어로 만들어진 같은 길이의 비단어 라도 해당 언어의 단어들과 비단어 사이의 유사성과 같은 비단어 의 음운 특성이 아동들의 수행에 영향을 미친다는 사실이 밝혀졌 다(Gathercole, 1995; Munson, Kurtz, \& Windsor, 2005). Graf Estes, Evans와 Else-Quest (2007)은 영어권에서 단순언어장애아동 들을 대상으로 진행된 비단어 따라말하기 연구들을 망라하여 분 석하였는데, 연구들에 사용된 비단어 따라말하기 검사들은 비단 어 항목의 개수, 비단어의 길이, 조음복잡성, 단어유사성, 검사 실 시 방법, 채점 방식 등 검사의 여러 측면에서 매우 다양한 특성을 보
였다. Graf Estes 등(2007)에 의하면 연구에 참여한 아동들의 연령 이나 통제집단의 특성 등 연구마다 다른 측면들과 더불어 이러한 검사도구 상의 다양성으로 인해 단순언어장애아동과 일반아동 사 이의 수행 차이의 정도가 연구마다 다르게 나타날 수 있다는 것이 다. 즉, 비단어 따라말하기가 언어발달지체아동들을 선별하는 데 유용한 검사이나, 이 검사의 언어장애 선별 정확도는 언어에 따라 다르게 나타날 수 있고, 검사를 구성하는 비단어의 특성이나 검사 방법상의 차이에 의해서도 영향을 받을 수 있다.

언어발달과 처리에 어려움을 겪는 한국 아동들의 비단어 따라 말하기 수행에 관련된 연구는 영어권 연구들에 비교할 때 상대적 으로 많지 않다. Yang, Yim, Kim과 Han (2013)의 연구에서 2-6세 어휘발달지체아동들이 생활연령을 일치시킨 또래 아동들에 비해 비단어 따라말하기 수행이 유의미하게 저조하였고, Park과 Hwang (2011)에서는 5-6세 단순언어장애 아동들이 언어능력을 일치시킨 어린 일반아동들에 비해서도 비단어 따라말하기 수행이 유의미하 게 저조하다고 보고하였다. 언어장애 자체는 아니지만 다른 다양한 이유로 언어발달에 어려움을 겪는 아동들의 비단어 따라말하기 수행이 이중언어사용 아동(Hong \& Yim, 2014), 조음장애아동(Kim \& Ha, 2014; Lee \& Sim, 2003), 인공와우수술을 받은 청각장애아동 (Lee, Yim, \& Sim, 2012) 등을 대상으로 조사되었는데, 이 아동집단 들 또한 일반아동에 비하여 비단어 따라말하기에서 저조한 수행 을 보였다. 이렇듯 다양한 특성을 가진 아동들이 비단어를 정확히 따라말하기 어려운 데에는 음운작업기억뿐 아니라 비단어에 대한 청지각이나 조음 능력 등이 서로 다른 정도로 영향을 미쳤을 것으 로 보인다. 그런데, 언어처리의 어려움을 갖는 아동들이 모두 비단 어 따라말하기 수행이 저조한 것은 아니었다. 2-3세의 말늦은 아동 들이나(Oh \& Yim, 2013), 초등학교 고학년 읽기이해부진 아동들 (Hwang, 2014)은 비단어 따라말하기가 또래 일반아동들과 다르지 않았다. 말늦은 아동이나 읽기부진 아동들이 언어발달지체로 진 단된 Yang 등(2013)이나 Park과 Hwang (2011)의 연구대상들과 동 질적인 언어결함을 가지고 있다고 볼 수는 없다. 그러나, 어린 아동 의 늦은 표현어휘 능력이나 학령기 시기의 읽기부진이 단순언어장 애와 갖는 연관성을 고려할 때, 한국어를 사용하는 아동들의 경우 비단어 따라말하기 수행에 기반하여 언어장애를 의심하는 것에 신 중을 기할 필요가 있다. 또한, 연구 대상의 연령 면에서 Oh와 Yim (2013)의 아동들은 2-3세로 아주 어렸고, Hwang (2014)의 연구대 상은 초등학교 고학년이었던 점을 고려하면, 한국어 비단어 따라 말하기 검사의 언어장애 선별 정확도는 아동의 연령에 영향을 받을 가능성을 제기할 수도 있다.

비단어 따라말하기 검사수행에 한국어의 특성이 어떻게 반영되 
는지를 확인하기 위해서는 일반아동들의 비단어 따라말하기 수행 이 아동의 연령이 증가하면서 어떻게 변화하는지를 보여주는 기초 자료가 필요하다. 한국 일반아동의 비단어 따라말하기 수행의 발 달적 변화를 조사한 연구는 2-5세 아동을 대상으로 한 Hwang과 $\mathrm{Ha}$ (2010)의 연구뿐이다. Hwang과 $\mathrm{Ha}$ (2010)에서 아동들은 연령 이 증가할수록 비단어 따라말하기 수행이 향상되었다. 연령 증가 에 따른 따라말하기 수행의 변화는 음절수가 긴 비단어에서 두드 러졌는데, 전체적으로 아동들은 1-4음절로 구성된 비단어의 길이 가 길수록 비단어를 따라말하는 정확도가 떨어졌지만 이러한 경 향은 연령이 증가할수록 줄어들어서, 5 세 아동들은 4 음절 비단어 도 전체 음소의 $95 \%$ 를 정확하게 따라 말하였다. 그런데, 다른 비단 어 따라말하기 검사와 달리, Hwang과 $\mathrm{Ha}$ (2010)의 연구에서는 필 요한 경우 3 회까지 아동에게 비단어를 반복하여 들려주었는데, 이 러한 검사 실시 방법은 비단어에 대한 아동의 음운작업기억을 측 정하는 것보다는 아동의 조음능력에 초점을 둔 방법으로 보인다.

본 연구의 목적은 한국어를 사용하는 5-9세 일반 아동들의 비단 어 따라말하기 수행 양상에 대한 기초 자료를 마련하고자 하는 것 이다. 본 연구에서는 비단어의 길이와 조음복잡성이 한국 아동의 비단어 따라말하기 수행에 어떠한 영향을 미치는지, 이러한 수행 양상이 채점양식에 따라 달라지는지를 조사하고자 하였다. 구체적 으로, 본 연구에서는 연령 증가에 따른 비단어 따라말하기 수행에 서의 변화가 한국어를 사용하는 5-9세 아동들에서도 나타나는지 확인하고자 하였다. 비단어의 길이와 조음복잡성은 언어장애 아동 들을 선별하는 검사도구로써 비단어 따라말하기 검사의 정확성에 영향을 미치는 중요한 요인이다. 단순언어장애 아동들의 비단어 따 라말하기 수행을 일반아동들과 비교한 많은 연구들에서 단순언어 장애 아동들의 저조한 수행은 긴 비단어에서 특히 두드러지게 나 타남을 일관되게 보고해왔다(Dollaghan \& Campbell, 1998; Ellis

Weismer et al., 2000; Munson et al., 2005). 단순언어장애아동이 모 두 뚜렷한 조음문제를 보이는 것은 아니지만, 조음발달의 지체와 미세한 구강운동결함을 겪는 아동들이 많다는 사실이 밝혀진 바 있으며(Roberts, Rescorla, Giroux, \& Stevens, 1998; Stark \& Blackwell, 1997), Gallon, Harris와 Van der Lely (2007)의 연구에서 단순 언어장애 아동들은 조음복잡성이 낮은 비단어보다 높은 비단어에 대한 따라말하기 수행이 유의미하게 저조하였다. 본 연구에서는 비 단어 따라말하기에 대한 이 두 변인의 영향이 정상적으로 발달하 는 한국 아동에 있어서 연령에 따라 어떻게 나타나는지를 조사하 고자 하였다. 선행연구들에서 비단어 따라말하기 검사에 대한 채 점 방법은 영어권 연구들의 경우, 비단어의 모든 음소를 정확히 따 라 말해야 1 점을 주는 항목단위 채점을 사용하거나, 비단어의 전체
음소 중 아동이 정확히 따라 말한 음소의 비율을 측정하는 음소단 위 채점을 사용하였으나, 한국 아동들에 대한 연구에서는 정확히 따라 말한 음절의 비율을 측정하는 음절단위 채점기준을 적용한 연구들도 많다(Hwang, 2014; Kim \& Ha, 2014; Oh \& Yim, 2013; Yang et al., 2013). 이는 한국어 단어 인식이 음절단위로 이루어진 다는 선행연구 결과(Lee \& Park, 1997)에 기반한 것이다. 본 연구에 서는 아동들의 비단어 따라말하기 수행에 대해서 항목단위와 음 절단위채점기준을 적용하여 채점하고, 두 가지 채점양식에서 아동 의 연령이나 비단어의 길이 및 조음 복잡성이 비단어 따라말하기 수행에 미치는 영향이 다르게 나타나는지 조사하였다.

\section{연구 방법}

\section{연구 대상}

경기와 충청지역 유치원과 초등학교에서 연구대상을 모집하였 다. 부모나 교사의 보고에 의거해 모든 아동들은 정상적으로 발달 하며 행동 정서 청력 및 신경학적 결함이 없었다. 각 연령별로, 5 세 36 명, 6세 37명, 7세 24명, 8세 25명, 9세 30명으로 총 인원 152명이 실험에 참가하였다.

\section{검사 도구}

본 연구의 비단어 따라말하기 검사에 포함된 항목들은 총 32 개 의 비단어인데, 조음복잡성에 따라 두 부류로 나뉘었다. 단어의 조 음복잡성은 단어의 길이, 강세나 운율 굴곡의 양상 등을 포함하여 다양한 변인에 의해서 결정되는데, 비단어 따라말하기에 대한 선행 연구들에서 비단어의 조음복잡성은 주로 비단어에 자음군(consonant cluster)이나, 발달적으로 나중에 습득되는 자음들이 포함 되는지 여부에 근거하여 판단되었다(Gathercole, 1995; Gathercole et al., 1994; Graf Estes et al., 2007). 본 연구의 모든 비단어에는 발 달적으로 나중에 습득되는 자음들을 제외시켰기 때문에, 조음복 잡성의 구분은 종성 자음 포함 여부에 근거하였다. 조음 복잡성이 낮은 16 개 비단어는 모든 음절에 종성이 없는 $\mathrm{CV}$ 구조의 연속이었 고, 조음복잡성이 높은 나머지 16개 비단어에는 각 비단어당 1-2개 의 종성이 포함되었다. 이는 Gathercole 등(1994)이 제작한 비단어 따라말하기 검사에서 절반의 비단어들은 $\mathrm{CV}$ 음절 구조로만 구성 되고, 나머지 절반의 항목들은 자음군을 포함하는 것과 유사하다. 조음복잡성 조건별로 2 음절부터 5 음절까지 각각 4 개의 비단어를 제작하였다. 조음복잡성이 높은 비단어 안에서 종성을 포함하는 음절이 연속되지 않도록 하였고 종성이 포함된 음절의 위치를 고정 하지 않고 다르게 하였다. 
본 연구에서 사용된 비단어의 단어 유사성은 한국어의 음운전 이 빈도에 기반하여 체계적으로 조작되었다. 비단어의 단어유사성 은 여러 가지 방법으로 조절 가능한데, 제작된 비단어가 얼마나 단 어와 비슷하게 느껴지는지 주관적으로 평정하는 방법, 단어의 이웃 밀도(neighborhood density)나 음소전이 확률(phonotactic probability)에 기반하여 비단어에 포함된 음소연쇄들을 정하는 방법들이 있다(Bailey \& Hahn, 2001; Gathercole, 1995; Munson et al., 2005). 이웃밀도가 비단어 처리에 미치는 영향에 대해서는 연구들마다 다 소 상이한 결과들을 보고하였지만(Bailey \& Hahn, 2001; Lipinski \& Gupta, 2005), 음소전이 확률이 높을수록 단어 유사성이 높으며 비단어 따라말하기 수행이 향상되는 것은 일관되게 관찰되어 왔다 (Dollaghan \& Campbell, 1998; Edwards, Beckman, \& Munson, 2004; Munson et al., 2005; Vitevitch \& Luce, 2005). 예를 들어 “기” 나 “누”와 같이(예: 김, 기린, 눈, 누르다 등) 한국어 단어에서 자주 출현하는 음소배열을 포함하는 비단어(예: 기누)는 “죠”나 “페”와 같이 한국어 단어에서 잘 출현하지 않는 음소배열을 포함하는 비 단어(예: 페죠)보다 단어와 유사하게 인식되며, 단어와 유사한 비단 어들을 따라말하기가 더 수월하다는 것이다.

Gathercole (1995)은 단어유사성이 높은 비단어보다 단어유사성 이 낮은 비단어에 대한 따라말하기 수행이 숫자폭이나 단어폭 검 사와 같은 음운기억 측정치와 더 높은 상관을 보이므로 단어유사 성이 낮은 비단어들이 아동의 음운작업기억 능력을 더 민감하게 반영한다고 주장한 바 있다. 본 연구에서는 단어유사성이 상대적 으로 낮은 비단어들을 제작하고자 음소전이 확률이 상대적으로 낮은 음소연쇄들로 비단어를 구성하되, 한국어 단어에서 거의 출 현하지 않는 음소배열은 제외하고자 하였다. 음소전이 확률을 측정 하는 방법은 분석에 포함되는 음소의 수, 음소의 음절 내 위치에 대 한 고려 등 여러 측면에서 연구들마다 다를 수 있지만, 흔히 사용되 는 방법들 중 하나가 두 개의 음소가 발화 자료에서 함께 출현하는 확률을 측정하는 것이다(Bailey \& Hahn, 2001). Shin (2008)은 한 국 성인의 발화표본에서 한 음절에 포함된 인접한 두음소 연쇄(biphones)가 출현하는 확률을 조사한 바 있는데, 본 연구에서는 Shin (2008)의 음소전이 확률에 기반한 기준을 바탕으로 비단어를 제작 하였다. 우선 한 음절 내 인접한 두 음소 연쇄의 누적빈도가 상위 $50 \%$ 에 해당하는 음소(예: 가, 지)들을 제외함으로써 단어 유사성 이 상대적으로 낮은 비단어들을 구성하였다. 그러나 출현 빈도가 극히 낮은 두 음소 연쇄로 구성된 비단어는 한국어 말소리로 인식 되지 않기 때문에, 음절 내 연결된 두 음소의 전이빈도가 $0.1 \%$ 이하 인 음소연쇄는(예: 투, 삐) 포함시키지 않았다. 또한, 발달적으로 나 중에 습득되는 자음들(ㅅ, 씨, 초성 르) 및 이중모음은 비단어에 포
함시키지 않았으며, 청각적으로 유사하여 혼동될 수 있는 모음들 은 하나만 사용하였다(예:/게/와///).

기본적으로 비단어 내의 음절들은 한국어 단어를 포함하지 않 아야 한다. 그러나, 한국어에는 중국어의 영향으로 한 음절로 구성 된 한자어 단어가 많다. 일부 영어권 연구들과 같이 비단어 내의 한 음절도 단어가 아니어야 하는 기준을 적용한다면, 위의 음소전이 기준을 충족하는 음절들은 극히 드물기 때문에 충분히 다양한 자 음과 모음의 연쇄로 구성된 비단어를 제작하기 어렵다. 따라서 본 연구에서는 상기 음운특성의 기준을 충족하는 음소연쇄로 구성 된 비단어 내에서, 연속하는 두 개의 음절이 한국어 단어가 되지 않 도록 비단어를 제작하였다. 일차 제작된 비단어 중 일부는 일반아 동 5 명과 언어장애아동 3 명을 대상으로 한 예비검사 결과에 근거 하여 수정되었다. 초성 자음은 상기 기준에 부합되는 한도에서 다 양한 자음들을 비단어에 포함시켰고 상대적으로 유형의 개수가 적 은 모음과 종성 자음 각각이 비단어에 포함되는 빈도를 비슷하게 맞추었으며, 음운구조 유형별, 그리고 각 음절별로 특정 모음과 종 성이 고르게 분포되도록 배치하였다. 한국어의 7 개 종성 중 ㄷ은 예비검사 결과 아동들이 종성 ㄱㄱㄱㅘ 음향학적으로 구분하기 어려 워하는 경향을 보였기 때문에 사용하지 않았다. 비단어 목록은 Appendix 1에 제시하였다.

확정된 비단어 목록은 전문 성우에게 의뢰하여 자연스럽게 발음 하도록 연습시킨 후 소음이 차단된 전문 녹음시설에서 녹음하였 다. 각 비단어를 발음하는 속도는 Dollaghan과 Campbell (1998)에 서 보고된 음절 길이별 비단어 발음 속도를 참조하여 지나치게 느 리거나 빠르지 않은 일반 속도를 유지하도록 연습시켰다. 개별 음성 파일로 제작된 비단어들은 조음복잡성에 따라 두 개의 목록으로 나누어 저장하였는데, 비단어 음성 파일은 MP3에 조음복잡성 조 건별로 2 음절, 3 음절, 4 음절, 5 음절 비단어의 순서로 재생되도록 배 열하였으며, 각 비단어 파일들 사이에는 3 초의 휴지기간을 삽입하 여 비단어를 듣고 아동이 따라말할 수 있는 시간을 두었다.

\section{실험 절차 및 채점 방법}

실험은 아동이 재학하는 유치원과 학교의 조용한 교실에서 일대 일로 실시하였으며 특히 소음의 영향을 최소화할 수 있는 장소를 택하였다.

비단어 따라말하기 검사 절차는 다음과 같다. 검사자와 마주보 고 앉은 아동에게 검사에 대한 지시문을 읽어주어 검사 절차를 설 명하고 2 개의 연습용 비단어를 이용하여 연습시행을 실시하였다. 아동이 검사절차를 파악하지 못한 경우 검사 절차를 이해할 때까 지 연습시행을 반복하였다. 연결잭을 이용하여 두 개의 이어폰을 
비단어 재생용 MP3에 동시에 연결하고 하나는 아동이, 하나는 검 사자가착용하여 아동에게 들리는 비단어를 검사자도 확인하였다. 검사자는 아동의 주의집중을 확인하고 검사를 시작하였다. 검사자 는 별도의 녹음용 MP3에 연결된 마이크를 아동의 입 근처에 위치 시켜 아동의 모든 반응을 녹음하였다. 전체 문항은 한 번만 들려주 는데, 단 주변 소음으로 인해 아동이 제대로 듣지 못한 것으로 판단 된 경우에는 검사가 끝난 후 해당 비단어만 검사자의 입을 가리고 육성으로 한 번 들려주었다. 검사를 실시하는 동안 검사자는 아동 의 반응을 녹음하는 동시에 아동의 입모양까지 관찰하여, 모든 음 소를 정확히 따라 말한 경우 바로 표시하고, 틀린 음소가 있는 경우 가능한 즉시 검사지에 기록하였으나, 비단어 간 휴지기간 3 초를 넘 기지 않는 조건에서 검사를 진행하였다. 검사자는 검사 종료 후 녹 음된 아동의 발화를 들으며 모든 반응을 정확히 전사하였다.

채점 방법은 항목단위와 음절단위의 2 가지 채점방식을 시행하 였다. 항목단위 채점에서는, 아동이 비단어를 완벽하게 따라 말한 경우 1 점, 비단어의 음소가 하나 이상 틀린 경우는 0 점으로 채점하 였다. 따라서 가능한 최대점수는 각 음절길이 별로 8점씩 총 32점이 다. 음절단위 채점방식에서는 아동이 정확하게 발음한 음절에 1 점 을, 음절 내 음소가 하나라도 틀린 경우 0점을 주었다. 예를 들어, 3 음절 비단어를 완벽하게 따라말하면 3점을 부과하였다. 음절단위 채점의 최대점수는 비단어의 길이에 따라 다르기 때문에, 비단어 의 길이별로 전체 음절 수 중 아동이 정확하게 따라 말한 음절 수의 비율을 구하였다.

\section{자료분석}

두 가지 채점 방식에 근거한 비단어 따라말하기 검사 점수 각각 에 대해서 연령(5) $\times$ 조음복잡성 $(2) \times$ 비단어길이(4)의 혼합삼원분 산분석을 실시하여 아동의 연령에 따라 조음복잡성과 비단어길이 가 비단어 따라말하기 수행에 미치는 영향을 살펴보았다. 본 연구 자료들의 통계 처리를 위해 SPSS Windows 18.0 프로그램을 사용 하였다.

Table 1. Number of correctly repeated items in the nonword repetition test

\begin{tabular}{lccc}
\hline & Phonologically simple & Phonologically complex & Total \\
\hline Age (yr) & & & \\
5 & $9.69(3.05)$ & $6.97(2.32)$ & $16.67(4.36)$ \\
6 & $11.02(2.36)$ & $7.76(2.83)$ & $18.78(4.50)$ \\
7 & $10.79(2.87)$ & $7.96(2.59)$ & $18.75(4.88)$ \\
8 & $12.72(2.18)$ & $10.00(2.53)$ & $22.72(4.01)$ \\
9 & $12.76(1.65)$ & $9.60(1.89)$ & $22.36(2.77)$ \\
Average & $11.30(2.74)$ & $8.34(2.69)$ & - \\
\hline
\end{tabular}

Values are presented as mean (SD).

\section{연구 결과}

아동들의 비단어 따라말하기 수행은 항목단위 채점과 음절단위 채점에 따라 두 개의 점수로 계산하였다. 항목단위 점수에 대한 연 령(5) $\times$ 조음복잡성 $(2) \times$ 비단어길이(4)의 혼합삼원분산분석 결과 연령의 주효과 $\left(F_{(4,147)}=11.923, p<.001, \eta_{\mathrm{p}}{ }^{2}=.245\right)$, 조음복잡성의 주효과 $\left(F_{(1,177)}=179.075, p<.001, \eta_{\mathrm{p}}{ }^{2}=.549\right)$, 비단어길이의 주효과 $\left(F_{(3,441)}=133.867, p<.001, \eta_{\mathrm{p}}{ }^{2}=.477\right)$ 가 유의미하였고, 비단어길이 와 연령의 상호작용 효과 $\left(F_{(12,441)}=2.132, p=.014, \eta_{\mathrm{p}}{ }^{2}=.055\right)$, 조음 복잡성과 비단어길이의 상호작용 효과 $\left(F_{(3,441)}=21.253, p<.001\right.$, $\left.\eta_{\mathrm{p}}{ }^{2}=.126\right)$ 또한 유의미하였다. 조음복잡성과 연령의 상호작용과 $\left(F_{(4,147)}=.296, p>.05\right)$, 조음복잡성 $\times$ 비단어길이 $\times$ 연령의 상호작 용 $\left(F_{(12,441)}=.438, p>.05\right)$ 은 통계적으로 유의미하지 않았다.

음절단위 점수는 정확히 발음한 음절들의 합이 전체 음절 수에 서 차지하는 비율을 구한 것이기 때문에 통계분석에서는 비율점수 에 대한 $\arcsin$ 변환을 실시하였다. 연령(5) $\times$ 조음복잡성 $(2) \times$ 음절 길이 $(4)$ 의 혼합삼원분산분석 결과 연령의 주효과 $\left(F_{(4,147)}=11.961\right.$, $\left.p<.001, \eta_{\mathrm{p}}{ }^{2}=.246\right)$, 조음복잡성의 주효과 $\left(F_{(1,147)}=196.458, p<.001\right.$, $\left.\eta_{\mathrm{p}}{ }^{2}=.572\right)$, 비단어길이의 주효과 $\left(F_{(3,441)}=58.608, p<.001, \eta_{\mathrm{p}}{ }^{2}=.285\right)$ 가 유의미하였고, 비단어길이와 연령의 상호작용 효과 $\left(F_{(12,441)}=1.988\right.$, $\left.p=.024, \eta_{\mathrm{p}}{ }^{2}=.051\right)$, 조음복잡성과 비단어길이의 상호작용 효과 $\left(F_{(3,41)}=23.827, p<.001, \eta_{\mathrm{p}}{ }^{2}=.139\right)$ 또한 유의미하였다. 조음복잡 성과 연령의 상호작용과 $\left(F_{(4,147)}=.365, p>.05\right)$, 조음복잡성 $\times$ 비단 어길이 $\times$ 연령의 상호작용 $\left(F_{(12,441)}=.917, p>.05\right)$ 은 통계적으로 유의 미하지 않았다. 정리하면, 아동들의 비단어 따라말하기 수행에 대 한 항목단위 점수와 음절단위 점수는 통계적으로 유사한 결과를 보여주었다.

비단어의 음운복잡성에 따른 연령별 비단어 따라말하기 수행의 평균은 항목단위 점수를 Table 1, 음절단위 점수를 Table 2에 제시 하였다.

Table 2. Percentage of correctly repeated syllables in the nonword repetition test

\begin{tabular}{cccc}
\hline & Phonologically simple & Phonologically complex & Total \\
\hline Age (yr) & & & \\
5 & $82.39(11.29)$ & $72.62(8.52)$ & $77.51(8.26)$ \\
6 & $85.57(8.50)$ & $75.19(12.97)$ & $80.38(9.89)$ \\
7 & $86.68(8.78)$ & $77.60(7.26)$ & $82.14(7.18)$ \\
8 & $93.00(5.31)$ & $84.79(9.39)$ & $88.89(6.62)$ \\
9 & $92.68(4.41)$ & $84.76(5.17)$ & $88.72(3.88)$ \\
Average & $87.62(9.18)$ & $78.43(10.46)$ & - \\
\hline
\end{tabular}

Values are presented as mean (SD). 
통계 분석 결과에서 보여주듯이, 두 채점 양식 모두에서 연령이 증가함에 따라 아동들의 비단어 따라말하기 수행은 향상되었고, 조음이 단순한 비단어에 대한 수행 정확도가 복잡한 비단어에 대 한 수행보다 높았다. 조음복잡성에 따른 비단어 따라말하기 수행 의 양상은 연령의 증가와상관없이 비슷하게 나타났다.

연령의 주효과에 대한 사후분석결과 또한 두 채점 양식에서 동 일하게 나타났는데, 인접한 연령에서 연령증가에 따른 수행의 차이 는 7세와 8 세 아동들 사이에서만 유의미하게 나타났으며, $5,6,7$ 세 아동들의 수행은 서로 유의미하게 다르지 않았고, 8 세와 9 세 아동 들 사이의 수행차이도 유의미하지 않았다. 요약하면, 비단어 따라 말하기 수행에서 통계적으로 유의미한 연령간 차이는 5 세 $=6$ 세 $=$ 7 세 $<8$ 세 $=9$ 세의 양상으로 나타났다.

Figures 1 과 2 는 비단어의 길이와 조음복잡성에 따라 비단어 따 라말하기 수행이 변화하는 양상을 보여준다. Figure 1에서 드러나 듯이 항목단위 점수에서는 음절수가 증가할수록 비단어 따라말하 기 수행 정확도가 낮아졌는데, 사후분석 결과 5 음절 비단어에 대한

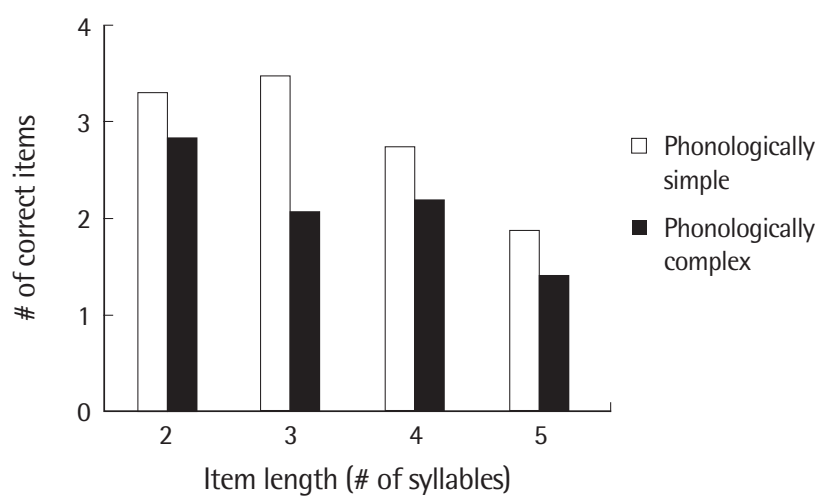

Figure 1. Average number of correct items according to item length and phonological complexity.

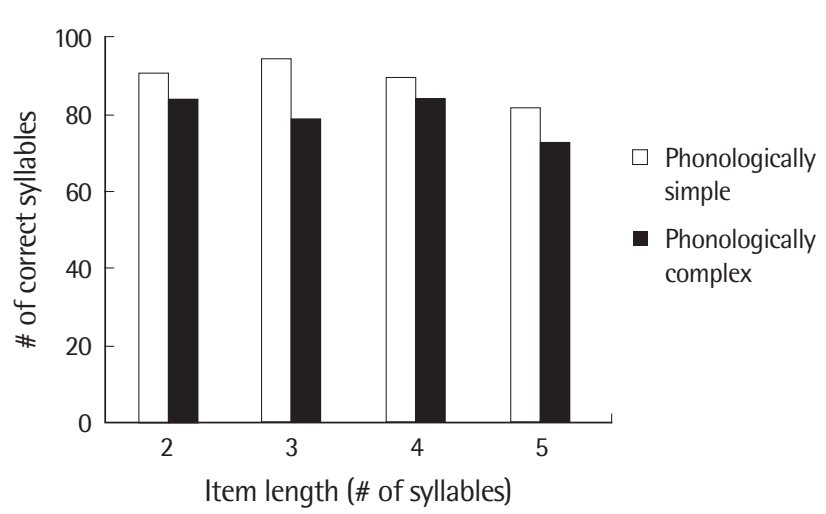

Figure 2. Average percentage of correct syllables according to item length and phonological complexity.
수행이 4 음절 비단어에 대한 수행보다 유의미하게 낮았고 $(p<.001)$, 4 음절 비단어에 대한 수행은 3 음절 비단어보다 $(p<.001), 3$ 음절 비 단어에 대한 수행은 2 음절 비단어보다 유의미하게 낮았다 $(p<.001)$. 그러나, 음절 단위 점수에서는 5음절 비단어에 대한 수행이 나머지 $2,3,4$ 음절 비단어보다 유의미하게 낮았던 $(p<.001)$ 것을 제외하면 다른 음절들 사이에서는 유의미한 차이를 보이지 않았다. 또한, 항 목단위 점수와 음절단위 점수가 모두 통계적으로는 유의미한 비단 어 길이의 주효과를 보였으나, 항목단위 점수에서 비단어길이의 효 과크기가 $\eta_{\mathrm{p}}{ }^{2}=.477$ 인데 비하여 음절단위 점수의 효과크기가 $\eta_{\mathrm{p}}{ }^{2}=$ .285 인 것을 볼 때, 항목단위 점수가 비단어 길이의 증가에 더 크게 영향을 받는 것으로 나타났다.

조음복잡성과 비단어 길이 사이의 상호작용은 Figures 1 과 2에 서 보이듯이 다른 음절들에 비해 3 음절 비단어에 대한 수행에서 조 음복잡성에 따른 수행차이가 두드러지게 큰 데에서 기인하는 것으 로 보인다. 이러한 경향은 항목단위 점수와 음절단위 점수에서 모 두 나타났다.

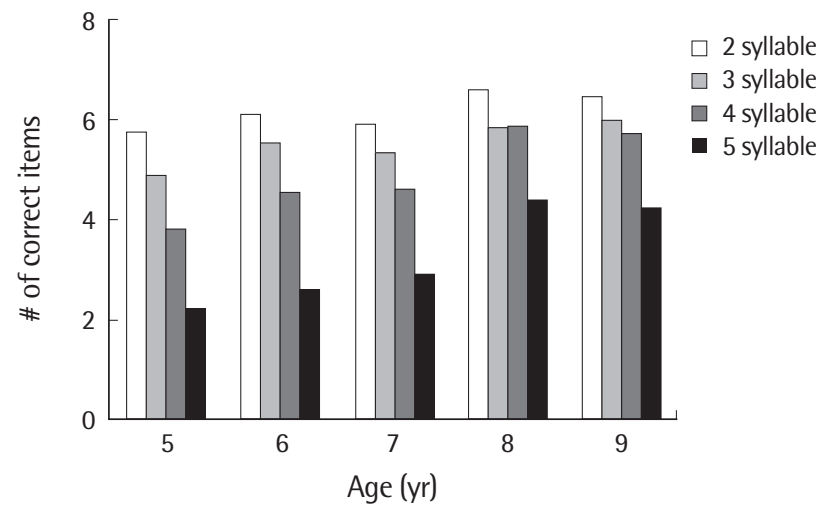

Figure 3. Average number of correct items according to item length and age group.

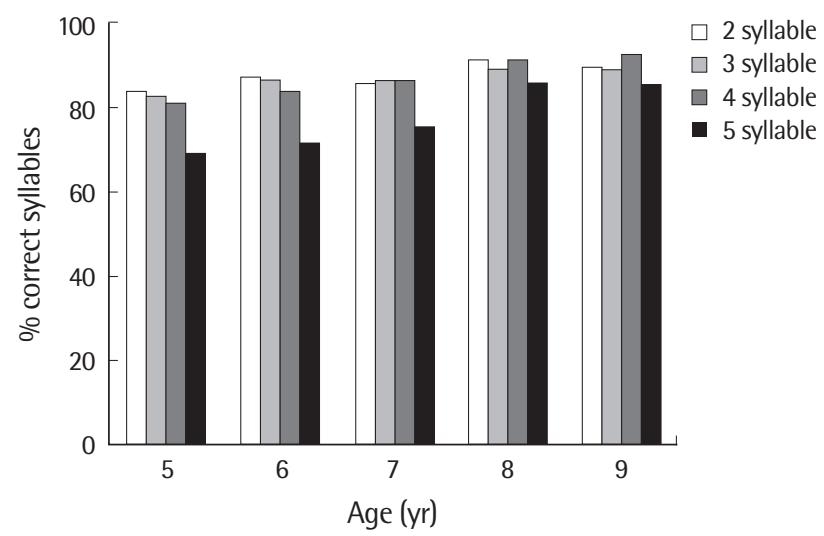

Figure 4. Average percentage of correct syllables according to item length and age group. 
끝으로, 연령과 비단어길이의 상호작용은 Figures 3 과 4 에서 관 찰할 수 있다. Figure 3 의 항목단위 점수분포에서 보이듯이 짧은 비 단어보다 긴 비단어에 대한 수행 정확도가 낮아지는 경향은 연령 이 증가함에 따라 감소하였다. 바꿔 말하면, 어린 아동일수록 2,3 음절의 짧은 비단어보다 4,5 음절의 긴 비단어를 따라말하는 데에 특히 어려움을 보였다. 아동의 연령이 증가하면서 비단어 따라말하 기 수행정확도가 향상되는 경향은 2,3 음절보다는 4,5 음절에서 더 큰 폭으로 나타났다. 이러한 경향은 Figure 4 의 음절단위 점수분포 에서도 유사하게 나타났다.

\section{논의 및 결론}

본 연구 결과 5-9세 아동들은 연령이 증가하면서 비단어 따라말 하기 수행이 향상되는 양상을 보였다. 또한, 모든 음절이 CV로 구 성된 비단어보다 종성을 포함하여 조음복잡성이 높은 비단어를 따라말하는 것이 유의미하게 어려웠다. 비단어의 길이가 길어질수 록 따라말하기 수행정확도는 떨어졌지만, 비단어길이에 따른 수행 변화의 폭은 아동의 연령이 증가할수록 줄어들었다.

아동의 연령이 증가함에 따라 비단어 따라말하기 수행이 향상 되는 것은 여러 선행연구들에서 보고된 바 있다. 서론에서 언급하 였듯이 아동의 비단어 따라말하기 수행에 영향을 미치는 요인들 은 청각변별 능력부터 음운표상, 음운작업기억, 조음 능력까지 다 양하기 때문에, 이러한 다양한 측면에서의 발달이 연령 증가에 따 른 비단어 따라말하기 수행의 향상에 영향을 미쳤을 것이다. 음운 작업기억의 측면에서도 연령이 증가하면서 기억용량 자체가 늘어 났을 수도 있지만, 제한된 기억용량을 사용하는 처리 효율성 또한 연령과 함께 증가했을 수 있다. 그런데 본 연구에서는 이러한 연령 에 따른 비단어 따라말하기의 수행 차이는 모든 인접 연령 사이에 서 유의미하지는 않았고, 8, 9세 아동들의 수행이 5, 6, 7세 아동들 의 수행에 비해서 유의미하게 향상되는 양상으로 나타났다. 6-9세 아동들을 대상으로 연구한 Archibald와 Joanisse (2009)에서도 비 단어 따라말하기 수행에서 연령의 주효과가 유의미하였지만 인접 연령에서는 수행차이가 유의미하지 않은 것으로 나타났다. 반면에 Chiat와 Roy (2007)에서는 2-4세 아동들을 6개월 기준으로 연령집 단을 구성했음에도 인접 연령집단들 사이의 수행 차이가 유의미하 게 나타났다. 본 연구의 결과와 선행연구의 결과들을 종합해 볼 때 아동의 연령이 어릴 때에는 연령 증가에 따른 비단어 따라말하기 수행의 향상 폭이 커서 인접연령 사이에서도 유의미한 차이를 보이 지만, 아동이 학령기에 가까워 지면서 연령 증가에 따른 비단어 따 라말하기 수행 향상의 폭이 줄어드는 것 같다. 그런데 어린 아동들
에서 연령 증가에 따른 비단어 따라말하기 수행의 향상 폭이 큰 것 이 반드시 음운작업기억의 용량 증가만을 반영하는 것은 아닐 수 있다. 학령 전 어린 아동들에서는 연령증가에 따른 음운지각이나 조음능력의 발달적 변화가 분명하기 때문에 이러한 발달적 변화가 비단어 따라말하기 정확도에 영향을 미쳤을 가능성이 크다.

조음복잡성이 높은 비단어보다 낮은 비단어에 대한 아동들의 따라말하기 수행이 더 정확한 본 연구의 결과도 선행연구(Gallon et al., 2007)와 일치한다. 이러한 조음복잡성에 따른 따라말하기 수 행의 차이는 모든 연령에서 비슷한 정도로 나타났다. 본 연구의 비 단어 따라말하기에서 연령과 조음복잡성의 상호작용이 유의미하 지 않은 이유 또한 조음발달과 관련지어 추정해볼 수 있는데, 본 연 구의 대상 아동들은 만 5 세 이상이어서 조음발달이 어느 정도 안 정화되었고 늦게 습득되는 음소들도 비단어에서 제외되었기 때문 에 일부 음절들에 종성이 포함되는 정도의 조음복잡성 증가로는 연령에 따른 차이를 기대할 수 없다고 보인다.

비단어의 길이가 길어지면 아동의 따라말하기 수행이 저조해지 는 결과들도 역시 선행연구들의(Hwang \& $\mathrm{Ha}, 2010 ;$ Munson et al., 2005)결과와 일치한다. 본 연구의 결과와 더 어린 한국 아동들 을 대상으로 한 Hwang과 $\mathrm{Ha}$ (2010)의 연구결과는 자세히 비교해 볼 필요가 있다. 본 연구에서 연령 증가에 따라 비단어 따라말하기 수행이 향상되는 현상은 2,3 음절로 구성된 짧은 비단어보다 4,5 음 절로 구성된 긴 비단어에 대한 따라말하기 수행에서 뚜렷이 나타 났다. Hwang과 $\mathrm{Ha}$ (2010)의 연구에서도 연령 증가에 따른 비단어 따라말하기 수행의 향상은 1,2 음절의 짧은 비단어보다 3,4 음절의 긴 비단어에서 두드러짐을 보고하였다. 그런데, Hwang과 $\mathrm{Ha}$ (2010) 에서 5 세 아동의 비단어 따라말하기 수행 정확도는 1,2 음절 비단 어에서 $100 \%, 3$ 음절에서 $98 \%$, 4 음절 비단어에서 조차 $95 \%$ 이었던 데 반하여, 본 연구에 참여한 5 세 아동의 경우 $2,3,4$ 음절 비단어에 대한 수행은 음절단위 점수에서 각각 $83.9 \%, 82.7 \%, 81.2 \%$ 로 나타 났다. 두 연구에서 나타난 아동들의 수행 차이는 연구방법의 차이 에 기인한 것 같다. 비단어의 특성에서 Hwang과 $\mathrm{Ha}$ (2010)는 어린 아동들의 조음발달 특성을 고려하여 7 개의 자음과 3 개의 모음만 으로 비단어를 제작하였으며, 2 음절과 3 음절 비단어의 일부는 자 음을 포함하지 않는 모음의 연쇄로 구성되는 등 조음 복잡성이 낮 은 비단어들인데 반하여, 본 연구의 비단어들은 모든 음절에 초성 자음이 있었고, 일부 음절에는 종성자음도 포함되었다. 채점 방식 에서도 Hwang과 $\mathrm{Ha}$ (2010)는 음소단위로 채점하여, 본 연구의 항 목단위 및 음절단위 채점보다 따라말하기의 수행정확도가 높게 나 타났을 수 있다. 무엇보다 중요한 차이는 검사 실시 방법이었는데, Hwang과 $\mathrm{Ha}$ (2010)에서는 검사자가 아동에게 비단어를 직접 말 
하여 들려주었지만, 본 연구에서는 비단어를 녹음하여 들려주었기 때문에 아동들은 비단어를 들을 때 입모양의 시각적 단서를 활용 할 수 없었다. 또한, 본 연구에서는 아동에게 비단어를 한 번만 들려 주었고, 소음으로 인하여 아동이 비단어를 제대로 못 들었다고 판 단되는 예외적인 경우에만 모든 시행이 끝나고 해당 비단어를 한 번만 더 들려주고 따라 말하게 한데 반하여, Hwang과 $\mathrm{Ha}$ (2010)는 아동이 반응이 없는 경우 비단어를 연속 3 회까지 반복해 주었기 때 문에 음운정보 기억의 부담이 적었다고 볼수 있다.

본 연구에서 아동들의 비단어 따라말하기 수행을 채점할 때, 항 목단위와 음절단위의 두 가지 채점양식을 적용하였는데, 두 채점양 식에 따른 점수는 전반적으로는 유사한 통계분석 결과를 보여주었 다. 그러나, 비단어의 길이에 따른 주효과에 대한 사후분석에서는 두 채점 양식이 다소 다른 결과를 보여주었는데, 항목단위 점수에 서는 인접한 길이들을 포함하여 모든 분석 쌍 사이의 수행차이가 유의미하였지만, 음절단위 점수에서는 5음절 비단어에 대한 수행 이 $2,3,4$ 음절 비단어에 비해 유의미하게 낮은 양상으로 나타났다. 또한, $\eta_{\mathrm{p}}{ }^{2}$ 으로 측정된 비단어 길이의 효과크기도 항목단위 점수가 음절단위 점수에서보다 더 큰 것으로 나타났다. 이러한 결과는 항 목단위 점수체계가 비단어 길이 차이에 따른 비단어 따라말하기 수행의 변화를 더 민감하게 반영한다는 것을 보여준다.

비단어 따라말하기 검사에서 어떠한 채점양식을 적용하는 것이 적절한지는 연구의 목적에 따라 달라질 수 있을 것 같다. 예를 들어, 비단어 따라말하기 수행에서 틀린(혹은 정확히 따라말한) 음소나 음절의 세밀한 특성을 조사하기 위해서는 음절이나 음소단위 채점 을 적용하는 것이 적절할 것이다. 반면에, 언어장애 아동들을 선별 하기 위해 비단어 따라말하기 검사를 실시할 때는 항목단위 채점 이 더 적절할 수 있다. 언어장애아동들이 일반아동들에 비해서 짧 은 비단어보다 긴 비단어 따라말하기에서 더 많은 오류를 보인다 는 사실이 여러 선행연구들에서 보고된 바 있으므로, 본 연구결과 비단어 길이에 따른 수행의 변화를 더 민감하게 반영하는 것으로 나타난 항목단위 점수가 음절이나 음소단위 점수보다 언어처리에 어려움을 보이는 아동들을 더 정확히 가려낼 수 있다. 또한, 임상장 면의 현실적인 제약을 고려해도 적용하기 간단하고 시간이 덜 소 요되는 항목단위 채점이 더 유용할 수 있다. 음절단위 채점을 위해 서는 검사하는 동안 아동 반응을 녹음한 후 다시 듣는 절차가 필요 하지만, 항목단위 채점은 검사에 숙달된 검사자의 경우 검사가 진 행되는 동안 실시간으로 채점을 마칠 수 있는 편리함이 있다. 궁극 적으로, 비단어 따라말하기 검사를 통하여 언어장애아동을 일반 아동으로부터 변별하는 정확도가 채점 방식에 따라 어떠한 영향을 받는지 확인하기 위하여 다양한 연령의 언어장애아동들과 일반아
동들을 비교하는 연구들이 실시되어야 한다.

비단어 따라말하기 검사의 임상적 유용성은 단순언어장애아동 들을 선별하는 정확도에 있다. 그런데, 비단어 따라말하기 검사의 다양한 특징들이 아동의 수행에 영향을 미치며 이러한 영향이 검 사 대상 아동의 연령에 따라 다르게 나타날 수 있기 때문에 특정한 비단어 따라말하기 검사를 모든 연령의 아동들에게 적용하기는 어 려울 수 있다. 예를 들어, 본 연구에서는 학령기 아동들까지 연구대 상에 포함하였기 때문에 비단어 검사의 난이도를 높이기 위해서 단어유사성이 낮은 비단어들을 제작하였고 비단어 제시 방법의 일 관성을 유지하기 위하여 녹음된 비단어를 사용하였다. 그러나, 훨 씬 어린 아동들을 대상으로 검사하는 경우에는 Oh와 Yim (2013) 이나 Hwang과 $\mathrm{Ha}$ (2010)에서처럼 비단어를 검사자가 육성으로 들 려주는 것이 어린 아동들이 비단어에 주의를 기울이게 하기에 더 적절할 수 있다. 또한, 본 연구에서는 검사가 단어유사성이 상대적 으로 낮은 비단어들로 구성된 점을 감안하여 5 음절까지만 비단어 를 제작하였는데, 10 세 이상의 고학년 아동이나 청소년에게 시행하 기 위해서는 더 긴 비단어들이 포함되어야 할 수 있다. 본 연구의 결 과 중 비단어의 길이와 조음복잡성의 상호작용이 유의미한 것은 다른 음절보다 3 음절 비단어에서 조음복잡성의 효과가 더 크게 나 타났기 때문인데, 이러한 결과는 3음절 비단어의 일반적 특성이라 기보다는 본 연구에서 3 음절 비단어를 제작하는 과정에서 의도치 않게 조음복잡성이 높은 비단어가 낮은 비단어보다 횔씬 어렵게 제작되었기 때문인 것 같다. 본 연구에서 각 음절과 조음복잡성 조 건 별로 해당하는 비단어 항목 수가 4 개뿐이었던 것이 이러한 의도 치 않은 결과에 영향을 미쳤던 것으로 보인다. 따라서 비단어 따라 말하기 검사를 제작할 때는 아동의 수행을 신뢰롭게 측정할 수 있 는 충분한 수의 비단어를 포함시키는 것이 필요하다.

\section{REFERENCES}

Archibald, L. M., \& Gathercole, S. E. (2006). Short-term and working memory in specific language impairment. International Journal of Language \& Communication Disorders, 41, 675-693.

Archibald, L. M., \& Joanisse, M. F. (2009). On the sensitivity and specificity of nonword repetition and sentence recall to language and memory impairments in children. Journal of Speech, Language, and Hearing Research, $52,899-914$

Bailey, T. M., \& Hahn, U. (2001). Determinants of wordlikeness: phonotactics or lexical neighborhoods? Journal of Memory and Language, 44, 568591. 
Bishop, D. V., North, T., \& Donlan, C. (1996). Nonword repetition as a behavioural marker for inherited language impairment: evidence from a twin study. Journal of Child Psychology and Psychiatry, 37, 391-403.

Bortolini, U., Arfé, B., Caselli, C. M., Degasperi, L., Deevy, P., \& Leonard, L. B. (2006). Clinical markers for specific language impairment in Italian: the contribution of clitics and non-word repetition. International Journal of Language \& Communication Disorders, 41, 695-712.

Chiat, S., \& Roy, P. (2007). The Preschool Repetition Test: an evaluation of performance in typically developing and clinically referred children. Journal of Speech, Language, and Hearing Research, 50, 429-443.

Conti-Ramsden, G. (2003). Processing and linguistic markers in young children with specific language impairment (SLI). Journal of Speech, Language, and Hearing Research, 46, 1029-1037.

Conti-Ramsden, G., \& Hesketh, A. (2003). Risk markers for SLI: a study of young language-learning children. International Journal of Language \& Communication Disorders, 38, 251-263.

Conti-Ramsden, G., Botting, N., \& Faragher, B. (2001). Psycholinguistic markers for specific language impairment (SLI). Journal of Child Psychology and Psychiatry, 42, 741-748.

Dollaghan, C., \& Campbell, T. F. (1998). Nonword repetition and child language impairment. Journal of Speech, Language, and Hearing Research, 41, 1136-1146.

Edwards, J., Beckman, M. E., \& Munson, B. (2004). The interaction between vocabulary size and phonotactic probability effects on children's production accuracy and fluency in nonword repetition. Journal of Speech, Language, and Hearing Research, 47, 421-436.

Ellis Weismer, S. Tomblin, J. B., Zhang, X., Buckwalter, P., Chynoweth, J. G., \& Jones, M. (2000). Nonword repetition performance in school-age children with and without language impairment. Journal of Speech, Language, and Hearing Research, 43, 865-878.

Gallon, N., Harris, J., \& Van der Lely, H. (2007). Non-word repetition: an investigation of phonological complexity in children with grammatical SLI. Clinical Linguistics \& Phonetics, 21, 435-455.

Gathercole, S. E. (1995). Is nonword repetition a test of phonological memory or long-term knowledge? It all depends on the nonwords. Memory \& Cognition, 23, 83-94.

Gathercole, S. E., \& Baddeley, A. D. (1989). Evaluation of the role of phonological STM in the development of vocabulary in children: a longitudinal study. Journal of Memory and Language, 28, 200-213.

Gathercole, S. E., \& Baddeley, A. D. (1990). Phonological memory deficits in language disordered children: is there a causal connection? Journal of Memory and Language, 29, 336-360.

Gathercole, S. E., Willis, C. S., Baddeley, A. D., \& Emslie, H. (1994). The children's test of nonword repetition: a test of phonological working memory. Memory, 2, 103-127.

Gathercole, S. E., Willis, C. S., Emslie, H., \& Baddeley, A. D. (1992). Phonological memory and vocabulary development during the early school years: a longitudinal study. Developmental Psychology, 28, 887-898.

Girbau, D., \& Schwartz, R. G. (2007). Non-word repetition in Spanish-speaking children with specific language impairment (SLI). International Journal of Language \& Communication Disorders, 42, 59-75.

Graf Estes, K., Evans, J. L., \& Else-Quest, N. M. (2007). Differences in the nonword repetition performance of children with and without specific language impairment: a meta-analysis. Journal of Speech, Language, and Hearing Research, 50, 177-195.

Hong, S., \& Yim, D. (2014). The assessment of language impairment in bilingual children through learning and memory tasks. Communication Sciences and Disorders, 19, 31-44.

Hwang, J., \& Ha, S. (2010). Nonword repetitions of 2- to 5-year-old typically developing children. Korean Journal of Communication Disorders, 15, 561571.

Hwang, M. (2014). Working memory of children with reading comprehension difficulty: sentence repetition and nonword repetition. Korean Journal of Learning Disability, 11, 53-72.

Kim, N., \& Ha, J. (2014). Phonological representations in children with articulation and phonological disorders. Communication Sciences and Disorders, 19, 226-237.

Lee, E., \& Sim, H. (2003). Phonological memory in the nonword repetition of children: a comparison of functional phonologically disordered and normal children. Korean Journal of Communication Disorders, 8, 127-145.

Lee, K., \& Park, H. (1997). The restoration of deep syllables and the role of syllables in Korean speech perception. Korean Journal of Cognitive and Biological Psychology, 9, 73-94.

Lee, Y., Yim, D., \& Sim, H. (2012). Phonological processing skills and its relevance to receptive vocabulary development in children with early cochlear implantation. International Journal of Pediatric Otorhinolaryngology, 76, 1755-1760.

Lipinski, J., \& Gupta, P. (2005). Does neighborhood density influence repetition latency for nonwords? Separating the effects of density and duration. Journal of Memory and Language, 52, 171-192. 
Montgomery, J. W. (1995). Examination of phonological working memory in specifically language-impaired children. Applied Psycholinguistics, 16, 355378.

Munson, B., Kurtz, B. A., \& Windsor, J. (2005). The influence of vocabulary size, phonotactic probability, and wordlikeness on nonword repetitions of children with and without specific language impairment. Journal of Speech, Language, and Hearing Research, 48, 1033-1047.

Oh, D. Y., \& Yim, D. (2013). Non-word repetition and sentence repetition performance in 2-3 years old late talkers and normal children. Communication Sciences and Disorders, 18, 277-287.

Park, K., \& Hwang, B. (2011). Phonological discrimination ability and phonological working memory of typically developing children and children with specific language impairments. Journal of the Korean Society of Speech Sciences, 3, 95-102.

Rispens, J., \& Parigger, E. (2010). Non-word repetition in Dutch-speaking children with specific language impairment with and without reading problems. British Journal of Developmental Psychology, 28, 177-188.

Roberts, J., Rescorla, L., Giroux, J., \& Stevens, L. (1998). Phonological skills of children with specific expressive language impairment (SLI-E): outcome at age 3. Journal of Speech, Language, and Hearing Research, 41, 374-384.

Roy, P., \& Chiat, S. (2004). A prosodically controlled word and nonword repetition task for 2- to 4-year-olds: evidence from typically developing children. Journal of Speech, Language, and Hearing Research, 47, 223-234.

Sahlen, B., Reuterskiold-Wagner, C., Nettelbladt, U., \& Radeborg, K. (1999).
Non-word repetition in children with language impairment-pitfalls and possibilities. International Journal of Language \& Communication Disorders, 34, 337-352.

Shin, J. (2008). Bi-phoneme frequency of Korean based on the analysis of spontaneous speech data. Korean Journal of Communication Disorders, 13, 477-502.

Stark, R. E., \& Blackwell, P. B. (1997). Oral volitional movements in children with language impairments. Child Neuropsychology, 3, 81-97.

Stokes, S. F., Wong, A. M., Fletcher, P., \& Leonard, L. B. (2006). Nonword repetition and sentence repetition as clinical markers of specific language impairment: the case of Cantonese. Journal of Speech, Language, and Hearing Research, 49, 219-236.

Thordardottir, E., Kehayia, E., Mazer, B., Lessard, N., Majnemer, A., Sutton, A., ... Chilingaryan, G. (2011). Sensitivity and specificity of French language and processing measures for the identification of primary language impairment at age 5. Journal of Speech, Language, and Hearing Research, $54,580-597$.

Vitevitch, M. S., \& Luce, P. A. (2005). Increases in phonotactic probability facilitate spoken nonword repetition. Journal of Memory and Language, 52, 193-204.

Yang, Y., Yim, D., Kim, S., \& Han, J. (2013). The relationship among receptive vocabulary, non-word repetition, and quick incidental learning in preschoolers with and without delay in vocabulary development. Communication Sciences and Disorders, 18, 379-391. 
Mina Hwang • Nonword Repetition of Typically Developing Children

Appendix 1. The list of nonwords

\begin{tabular}{|c|c|c|c|c|c|c|c|}
\hline \multicolumn{4}{|c|}{ 단순 음운구조 } & \multicolumn{4}{|c|}{ 복합 음운구조 } \\
\hline 2음절 & 3음절 & 4음절 & 5음절 & 2음절 & 3음절 & 4음절 & 5음절 \\
\hline 태누 & 무짜배 & 캐피저노 & 처바히무노 & 너붐 & 주돔처 & 곤쩌핼무 & 쟁꺼디눌비 \\
\hline 바또 & 머비빠 & 꼬미더배 & 보차두떠매 & 딩캐 & 딥태혼 & 카준모덩 & 배팜미놀저 \\
\hline 찌모 & 조너꾸 & 너부치모 & 호누카디머 & 눅짜 & 졸터누 & 갱머딜꾸 & 파보딕떠군 \\
\hline 버주 & 부더끼 & 따버매디 & 재누터미파 & 잴부 & 매넙또 & 치몬두낵 & 히캄더붕까 \\
\hline
\end{tabular}




\section{국문초록}

\section{일반아동의 비단어 따라말하기}

\section{황민아}

단국대학교 특수교육과

배경 및 목적: 비단어 따라말하기 검사는 언어장애 아동들을 선별하는 데 유용한 검사로 여러 언어권에서 사용되고 있으나, 검사의 여 러 가지 특성들이 따라말하기 수행에 영향을 미치는 것으로 보고되어 왔다. 본 연구의 목적은 한국어를 사용하는 5-9세 일반 아동들의 비단어 따라말하기 수행 양상에 대한 기초 자료를 마련하고자 하는 것으로, 비단어의 길이와 조음복잡성이 아동의 연령이 증가함에 따라 비단어 따라말하기 수행에 어떠한 영향을 미치는지 조사하고자 하였다. 방법: 5-9세의 한국어를 사용하는 일반아동 152 명이 연 구에 참여하였다. 2-5음절 길이의 비단어 32개가 제작되었는데 그중 반은 조음복잡성이 높고 나머지 반은 조음복잡성이 낮았다. 아동 들은 녹음된 비단어를 듣고 따라말하였으며 아동들의 수행은 항목단위와 음절단위 두 가지 양식으로 채점되었다. 결과: 연령(5) $\times$ 조 음복잡성(2) $\times$ 비단어길이(4)의 혼합 3 원 분산분석 결과 연령, 조음복잡성, 비단어길이의 주효과가 유의미하였고, 연령과 비단어길이, 조음복잡성과 비단어길이의 상호작용 효과가 유의미하였다. 즉, 아동의 연령이 증가할수록, 비단어의 길이가 짧을수록 비단어 따라말 하기 수행은 향상되었는데, 비단어길이의 효과는 연령이 어린 아동들에서 더 크게 나타났다. 논의 및 결론: 5-9세 한국어를 사용하는 일반아동들의 비단어 따라말하기 수행은 선행 연구들에서 보고된 것과 마찬가지로 연령, 비단어길이, 조음복잡성에 영향을 받는 것으 로 나타났다. 비단어 따라말하기 수행에 영향을 미치는 비단어의 특성, 검사실시 방법, 채점 양식에 대하여 논의하였다.

핵심어: 비단어 따라말하기 검사, 비단어길이, 비단어의 조음복잡성

이 연구는 2014학년도 단국대학교 대학연구비 지원으로 연구되었음.

\section{참고문헌}

김나연, 하지완 (2014). 조음음운장애아동과 일반아동의 음운표상의 질과 음운표상 부호화 능력 비교. 언어청각장애연구, 19, 226-237.

백경아, 황보명(2011). 일반 아동과 단순언어장애 아동의 음운변별 능력 및 음운작업기억 특성. 말소리와음성과학, 3, 95-102 신지영(2008). 성인 자유발화자료분석을 바탕으로 한 한국어의 음소전이 빈도. 언어청각장애연구, 13,477-502.

양윤희, 임동선, 김신영, 한지윤(2013). 학령 전 어휘발달지체 및 일반 아동의 비단어 따라말하기, 빠른 우연학습과 수용어휘와의 관계. 언어청각장애

연구, 18, 379-391.

오다연, 임동선(2013). 2-3세 말 늦은 아동과 정상 아동의 비단어 따라말하기와 문장 따라말하기 수행능력. 언어청각장애연구, 18, 277-287.

이광오, 박현수(1997). 음성지각과정에서음절의 역할과 기저음절의 복원. 한국심리학회지: 인지 및 생물, 9,73-94.

이은주, 심현섭 (2003). 무의미 음절 따라말하기를 통한 단순조음음운장애아동과 정상아동의 음운기억 수행능력 비교연구. 언어청각장애연구, 8, $127-145$.

홍성미, 임동선(2014). 학습 및 기억과제를 통한 이중언어아동의 언어발달지체 평가. 언어청각장애연구, 19, 31-44.

황민아 (2014). 읽기이해부진아동의작업기억 특성: 문장따라말하기 및 비단어 따라말하기 검사를 중심으로. 학습장애연구, 11, 53-72.

황진경, 하승희 (2010). 2-5세 일반아동의 무의미단어 따라말하기. 언어청각장애연구, $15,561-571$. 